\title{
Differences and Coordination Between Accounting and Tax Law
}

\author{
Huang Jing \\ Jiangxi College Of Foreign Studies
}

\begin{abstract}
There are wide differences between accounting standards, accounting system and tax laws in terms of the confirmation, measurement and operation methods of economic affairs, which have led to the smuggling of taxes in some enterprises. Meanwhile, it will continue to raise the financial accounting cost and taxes followed by tax-payers. Therefore, study should be conducted theoretically to seek proper countermeasures so as to solve existing problems in practice, which is the final purpose of this paper. According to the study, the fundamental reasons for the differences are environmental factors; while the different purposes, basic preconditions and followed principles between accounting and tax law are the direct reasons. The internal rationality and necessity of the differences between accounting and tax law have been summarized in this paper, and it proposes that the establishment of a top-down coordinated mechanism is the major measure to promote a harmonious relationship between the two parties.
\end{abstract}

Keywords-accounting; tax law; difference; coordination

\section{INTRODUCTION}

In the past 20 years since the reform and opening up, accounting practice has received a great development, which has provided broad survival space for theoretical study. Accounting system centered on accounting standards and accounting system has been established with constant development. At the same time, the framework of tax system based on tax laws, tax regulations and tax policies has also been established with constant expansion, during which two independent legal standards with interactive effects have been formed. With the long-term revolution, adjustment and improvement, the two legal systems have satisfied the market demand for standard institutional systems, but in fact, the accounting goals and the tax goals have become different gradually, which has brought many difficulties and obstacles for accounting practice and tax work and even some illegal acts. Thus some tax payment has run away indirectly.

In this paper, it explores the relationship between environment and accounting mode as well as tax goals under the circumstance of market economy with deep analysis on the influence of environment. Then the conclusion that environment is the fundamental reason for the differences between accounting and tax law can be drawn. Meanwhile, the rationality and necessity of the differences are further confirmed according to their differences in goals, basic preconditions and followed principles and so on.

Fundamental reasons for the differences between accounting and tax law

Generally speaking, the differences between accounting and tax law as well as the degree of difference depends on convergence or deviation between financial accounting goals and tax goals adopted by the country; while the convergence between the goals is determined by the accounting mode in this country. Certainly, the accounting mode in a country is the comprehensive result of many factors such as legal system, economic development level, enterprise financing source, tax system, political and economic relations, inflation, educational level and geographical conditions and so on.

\section{A. The reformation of economic system is the essential reason for the differences between accounting and tax laws.}

The position of taxation in government financial revenue has changed fundamentally since the establishment of market economic system. The policy of unified collection and allocation of funds has been implemented by government on enterprises under the planned economic mode. The main source of financial revenue is profit paid by enterprises. The position of taxation in fiscal revenue is insignificant. Under the market economic mode, enterprises should realize self development with independent operation, self-financing and self-discipline; while the country levies taxes in the legal forms. The main source of fiscal revenue is tax.

\section{B. The accounting goals and tax goals can be separated by the revolution of legislation procedure.}

China is a country with continental legal system, in which accounting behaviors and tax collection and 
management are standardized by authorized legislation institutions. The goals of both accounting and taxation have reflected the national will, which can be coordinated from the macro perspective. However, since the reformation of economic mode, market operation mechanism has centered on enterprises with deep changes

\section{MANIFESTATIONS OF DIFFERENCES BETWEEN ACCOUNTING AND TAX}

The separation of accounting and tax goals makes it difficult to deal with the same economic affairs due to different prescriptions and approaches, manifesting in the different confirmation standards, confirmation ranges, measurement methods and authorization policies of assets, debts, revenues and cost. The following contents are elaboration on the main differences.

\section{A. Differences of income confirmation and measurement}

This difference refers to different statements on the confirmation of income and interest by accounting and tax law. According to the accounting system, revenue refers to the overall economic income gained from sales, labor service and investment in daily activities, including main business income and other business income but without non-operating income.

\section{B. Difference of cost valuation and authorization methods}

As for the non-cash assets gained by debt restructuring or non-monetary trading, accounting system prescribes that the entry value should be credit receivable or assets surrendered together with related payable taxes. If it involves supplementary valency, the supplementary valency should be added or deducted to confirm the interest.

\section{REALISTIC REQUIREMENTS FOR THE COORDINATION OF DIFFERENCES BETWEEN ACCOUNTING AND TAX LAW}

The accounting mode implemented in China' $s$ market economy mechanism decides the separation of accounting calculation system from tax system. The different goals of accounting and tax law also lead to different basic preconditions, followed principles, prescription of concrete contents and operation methods, which has brought many contradictions, confusions, difficulties and obstacles to practice. The realistic of enterprise's ownership structure. Meanwhile, the ownership and managerial right have been separated with diversified investment subjects and interest allocations. Under the market economic background, enterprises' demand for various interests should be satisfied within the legislation.

problems resulted by differences need to be solved urgently.

\section{A. To lower the demand for following tax cost and improving work efficiency}

According to the prescriptions of current accounting mode and tax collection management system, accountants in enterprises should conduct daily accounting by the selected accounting standards and accounting system; however, when declaring paid taxes, differences of tax-related items should be adjusted in corresponding declaration form. Treatment addressing the differences should not change the process and result of accounting with exterior adjustment.

\section{B. The enterprises' taxpaying behaviors should be standardized and the quality of accounting information should be improved}

Although enterprises' calculation, declaration and taxpaying are prescribed by national laws, financial accounting has provided objective, detailed and reliable basis for tax payable for its accurate reflection on financial conditions, operation achievement and cash flow. Thus, accounting has been connected to tax law organically. Any change of accounting or tax contents will make a difference on the accounting materials and tax declaration.

\section{CONCLUSION}

At present, the economic mode in our country has transformed from the planned economy to market economy, during which the differences between accounting and taxation have presented objective necessity. The fundamental reason is the decisive effect of current environment on accounting and taxation goals. Separation of accounting and taxation goals has directly led to wide differences between the two systems regarding the definition and operation methods of basic preconditions, followed principles and related economic affairs. Besides, with the development of economy, the differences are becoming even larger. Such differences have resulted in many bad effects on practice such as 
smuggling of taxation as well as tax increase, which need to be dealt with urgently. When dealing with these problems, appropriate principle should be adopted. That is, a top-down systematic coordination scheme should be established while ensuring their independence respectively. Thus, accounting and taxation can be coordinated organically with increasingly perfect systems from macro field to micro sections, from policy formulation to personnel training and from quality education to supervision and inspection.

\section{REFERENCES}

[1] [1] Chatman, Jennifer Anna. Matching people and organizations : selection and socialization in public accounting firms. U.M.I., 1989:459-484.

[2] [2] Yang, Xingquan. "Financial accounting information and corporate governance." Ssrn Electronic Journal 32.01(2001):237-333.

[3] [3] Watts R L, Zimmerman J L. Towards A Positive Theory of the Determination of Accounting Standards[J]. Social Science Electronic Publishing, 2006, 53(1):112-134.
[4] [4] Holthausen $\mathrm{R}$ W, Watts $\mathrm{R}$ L. The relevance of the value-relevance literature for financial accounting standard setting[J]. Journal of Accounting \& Economics, 2001, 31(1):3-75.

[5] [5] Ball, Ray, and P. Brown. "An Empirical Evaluation of Accounting Income Numbers." Journal of Accounting Research 6.2(1968):159-178.

[6] [6] Watts, Ross L., and J. L. Zimmerman. "Positive Accounting Theory." Social Science Electronic Publishing 14.5(1986):455-468

[7] [7] Chari, V. V., P. J. Kehoe, and E. R. Mcgrattan. "Business cycle accounting." Working Papers 75.3(2002):781-836.

[8] [8] Sweeney A P. Debt-covenant violations and managers' accounting responses[J]. Journal of Accounting \& Economics, 1994, 17(94):281-308.

[9] [9] David Madigan, Adrian E. Raftery. Model Selection and Accounting for Model Uncertainty in Graphical Models Using Occam's Window $[\mathrm{J}]$. Journal of the American Statistical Association, 1994, 89(428):1535-1546.

[10] [10] Deangelo L E. Accounting Numbers as Market Valuation Substitutes: A Study of Management Buyouts of Public Stockholders[J]. Accounting Review, 1986, 61(3):400-420.

[11] [11] Estan, Cristian, and G. Varghese. "New Directions in Traffic Measurement and Accounting." Acm Sigcomm Computer Communication Review 32.4(2001):75--80.

[12] [12] Dechow P M, Skinner D J. 2000, Earnings management: Reconciling the views of accounting academics, practitioners, and regulators, Accounting Horizons[J]. Accounting Review, 2000, 14 